\title{
Helminthological screening of free-ranging grey brocket deer Mazama gouazoubira Fischer, 1817 (Cervidae: Odocoileini) from Brazilian Pantanal wetlands, with considerations on Pygarginema verrucosa (Molin, 1860) Kadenatzii, 1948 (Spirocercidae: Ascaropsinae)
}

\author{
Lux Hoppe, EG. ${ }^{\mathrm{a}, \mathrm{b} *}$, Tebaldi, $J \mathrm{H}^{\mathrm{a}}{ }^{\mathrm{a}}$ and Nascimento, $A \mathrm{~A}^{\mathrm{a}}$ \\ aDepartamento de Medicina Veterinária Preventiva e Reprodução Animal, \\ Faculdade de Ciências Agrárias e Veterinárias - FCAV, Universidade Estadual Paulista - UNESP, \\ Via de Acesso Prof. Paulo Donato Castellane, s/n, CEP 14887-900, Jaboticabal, SP, Brazil \\ ${ }^{\text {b}}$ Centro Universitário de Rio Preto - UniRP, Av. Yvette Gabriel Atique, 45, \\ CEP 15025-400, São José do Rio Preto, SP, Brazil \\ *e-mail: e.hoppe@gmail.com
}

Received December 19, 2008 - Accepted April 14, 2009 - Distributed May 31, 2010

(With 5 figures)

\begin{abstract}
The Brazilian Pantanal wetlands are a unique ecosystem with a faunistic composition similar to that of the adjacent biomes but in higher densities. The early establishment of domestic cattle husbandry in that area introduced pathogens that may influence the indigenous Pantanalian fauna. In this paper, the authors describe the helminthfauna of ten free-ranging adult Mazama gouazoubira from the Paiaguás sub-region, along with the descriptors of infection. Morphological description of Pygarginema verrucosa is supplied, with comments on other species of this genus. The helminth species found are similar to domestic cattle helminthfauna of the same physiographic region, suggesting an adaptation of bovine parasites to this host.
\end{abstract}

Keywords: Cervidae, Mazama gouazoubira, Brazilian Pantanal wetlands, helminthfauna, Pygarginema verrucosa, Brazil.

\section{Avaliação helmintológica de veados-catingueiros Mazama gouazoubira Fischer, 1817 (Cervidae: Odocoileini) de vida livre, procedentes do Pantanal brasileiro, com considerações sobre Pygarginema verrucosa (Molin, 1860) Kadenatzii, 1948 (Spirocercidae: Ascaropsinae)}

\section{Resumo}

O Pantanal brasileiro é um ecossistema único, com composição faunística semelhante à dos biomas adjacentes, mas com densidades superiores. O gado introduzido na região pode ter carreado patógenos nesse ecossistema que podem, de alguma forma, influenciar a fauna local. Neste artigo, é descrita a helmintofauna de dez indivíduos adultos de Mazama gouazoubira provenientes da sub-região de Paiaguás, juntamente com os indicadores de infecção helmíntica. Ainda, são fornecidas informações sobre a morfologia de Pygarginema verrucosa, com comentários sobre outras espécies deste gênero. As espécies de helmintos diagnosticadas são semelhantes àquelas encontradas em bovinos da mesma região, sugerindo adaptação destas no hospedeiro estudado.

Palavras-chave: Cervidae, Mazama gouazoubira, Pantanal brasileiro, helmintofauna, Pygarginema verrucosa, Brasil.

\section{Introduction}

The Brazilian Pantanal wetlands are a unique ecosystem comprised of areas of flooded plains, with faunistic composition similar to that of adjacent biomes, but in higher populational densities (Rodrigues et al., 2002).
Grey-brocket deer Mazama gouazoubira Fischer, 1814 is observed from Southern Mexico to Argentina, occurring in a great diversity of South American biomes (Nowak, 1999). In Brazil, this species is registered in almost all territories, always associated with forests. 
Unlike other deer species, they are generalists and consequently more tolerant to environmental changes (Pinder and Leeuenberg, 1997). Although this species is not included on extinction lists (IBAMA 2003, CITES 2006, IUCN 2006), its status still remains undefined due to the little information on subspecies distribution (Pinder and Leeuenberg, 1997).

It is known that exotic species introduced in a determined ecosystem may have a negative influence on biodiversity (Clout, 2002). In the early $18^{\text {th }}$ century, cattle herding started in the Brazilian Pantanal wetlands concomitantly with the Cuiaban gold rush, and the number of cattle herds in that region has increased since then. In the 1940's, the Pantanalian cattle herd represented $90 \%$ of the total Mato Grosso State (Catto et al. 1997). The similarity observed between bovine and cervid helminthfauna (Nascimento et al., 2000) may represent an evidence of cross transmission.

This study aims to evaluate and supply information on Brazilian pantanalian free-ranging grey brocket deer helminthfauna from the Paiaguás sub-region.

\section{Material and Methods}

\subsection{Study area}

The Brazilian Pantanal wetlands comprises a set of flooding plains in the High Paraguay River basin, with a total area of $138,183 \mathrm{Km}^{2}$, located between the states of Mato Grosso and Mato Grosso do Sul, in the Brazilian central region (Silva and Abdon, 1998). This ecosystem is greatly influenced by three adjacent biomes, Chaco, Amazonian rainforest and Cerrado savanna, which explains in part the heterogeneity of the pantanalian landscape (Silva et al., 2000). Silva and Abdon (1998) divide the Brazilian Pantanal wetlands into 11 sub-regions, determining the Paiaguás sub-region as the largest, with a total estimated area of $27,082 \mathrm{~km}^{2}$.

\subsection{Animals}

Aiming to evaluate their helminthfauna, ten adult grey brocket deer were captured in their natural habitat $\left(18^{\circ} 07^{\prime} 25^{\prime \prime} \mathrm{S}\right.$ and $\left.54^{\circ} 32^{\prime} 15^{\prime \prime} \mathrm{W}\right)$ by professional hunters, under license 061/95 Devis/IBAMA, between 1994 and 1997.

\subsection{Parasitological methods}

The animals were captured and subsequently necropsied. After detailed examination, the gastrointestinal tract was removed, partitioned in its anatomical segments, slit open and washed. Gastrintestinal contents were fixed and conserved in Railliet and Henry solution and sent to the Laboratory of Helminthology, Preventive Veterinary Medicine and Animal Reproduction Department of the Agrarian and Veterinary Sciences Faculty, São Paulo State University "Julio de Mesquita Filho", Jaboticabal, São Paulo State, Brazil.

The obtained helminths were clarified in $80 \%$ acetic acid solution and beechwood creosote or Amman's lactophenol. Morphometry was accomplished under Image Pro-Plus ${ }^{\circledR}$ v4.1 software, based on images obtained with an Olympus BX-51 ${ }^{\circledR}$ microscope equipped with a QColor ${ }^{\circledR}{ }^{\circledR}$ digital camera. Measurements of morphological characters are expressed in millimetres ( \pm standard deviation) and were based on five specimens of each sex, otherwise stated. Drawings were made with a drawing tube attached to a Carl-Zeiss ${ }^{\circledR}$ binocular microscope. Species identification followed Travassos (1937), Durette-Desset (1983), Gibbons and Khalil (1982), and Vicente et al. (1997). The descriptors of infection were elaborated based on Bush et al. (1997). All the helminths have been deposited at the FCAV Laboratory of Helminthology collection and vouchers were sent to the Helminthological Collection of the Instituto Oswaldo Cruz Foundation (CHIOC), Rio de Janeiro, Brazil.

\section{Results and Discussion}

All analysed animals were parasited by helminthes. Eight nematode species, divided in seven genera and four families, were diagnosed, with a parasitic species richness of 0.8 . Helminthfauna composition is detailed in Table 1, along with their quantitative descriptors and CHIOC deposit number. Species representing helminth Classes other than Nematoda were not found.

The parasite species found in these hosts are similar to those previously related by Silva et al. (1999) and Nascimento et al. (2000) in deer from the states of São Paulo and Mato Grosso do Sul, Brazil, and those of Uhart et al. (2003) in Argentinean Ozotocerus bezoarticus (Linnaeus, 1758). There was great similarity with the domestic Zebu cattle (Catto and Furlong, 1983) from the same physiographic area, Paiaguás sub-region, suggesting an adaptation of bovine parasites in M. gouazoubira, despite works of Prestwood et al. (1975), Prestwood et al. (1976) and Mckenzie and Davidson (1989) that relates little evidence on cross transmission between cervids and domestic species.

Remarkably, Haemonchus spp showed prevalences equal or higher than $60 \%$. Albon et al. (2002) demonstrated that Ostertagia gruehneri Skrjabin, 1929 has such an impact on Rangifer tarandus Linnaeus, 1758 that regulates the host population. Thus, the presence of high prevalences of a pathogenic helminth like Haemonchus spp could also interfere with $M$. gouazoubira populational dynamics.

Experimental infection of North American white-tailed deer Odocoileus virginianus (Zimmermann, 1780) (Foreyt and Trainer, 1970) with H. contortus (Rudolphi, 1803) Cobb, 1989 larvae obtained from domestic sheep evidenced the pathogenicity of this parasite in deer, and Prestwood and Kellogg (1971) reported the death of one free-ranging $O$. virginianus due to clinical haemonchosis, confirming the importance of Haemonchus spp in deer. Studies should be accomplished 
Table 1. Quantitative descriptors of helminthic infection observed in Mazama gouazoubira Fischer, 1817 from Brazilian Pantanal wetlands.

\begin{tabular}{|c|c|c|c|}
\hline \multirow{2}{*}{$\begin{array}{c}\text { Helminths } \\
(\text { CHIOC number })\end{array}$} & \multirow[t]{2}{*}{ Habitat } & \multicolumn{2}{|c|}{ Descriptors of infection } \\
\hline & & $\begin{array}{l}\text { Range of } \\
\text { intensity }\end{array}$ & $\begin{array}{l}\text { Mean intensity } \\
\text { (infected hosts) }\end{array}$ \\
\hline \multicolumn{4}{|l|}{ Secernentea } \\
\hline \multicolumn{4}{|l|}{ Strongylida } \\
\hline \multicolumn{4}{|l|}{ Trichostrongylidae } \\
\hline \multicolumn{4}{|l|}{ Trichostrongylinae } \\
\hline Trichostrongylus axei (Cobbold, 1879) (35560) & A & $01-08$ & $3.2(4)$ \\
\hline \multicolumn{4}{|l|}{ Haemonchinae } \\
\hline Haemonchus contortus (Rudolphi, 1803) (35564) & A & $01-26$ & $10.6(8)$ \\
\hline Haemonchus similis Travassos, 1914 (35563) & A & $01-167$ & $49.0(6)$ \\
\hline \multicolumn{4}{|l|}{ Cooperinae } \\
\hline Cooperia punctata (Von Linstow, 1907) (35565) & SI & $01-59$ & $16.2(6)$ \\
\hline \multicolumn{4}{|l|}{ Ancylostomatidae } \\
\hline \multicolumn{4}{|l|}{ Bunostominae } \\
\hline Bunostomum phlebotomum (Railliet, 1900) (35567) & SI & - & $2.0(1)$ \\
\hline \multicolumn{4}{|l|}{ Spirurida } \\
\hline \multicolumn{4}{|l|}{ Spirocercidae } \\
\hline \multicolumn{4}{|l|}{ Ascaropsinae } \\
\hline Physocephalus lassancei Travassos, 1921 (35562) & A & - & $77.0(1)$ \\
\hline Pygarginema verrucosa (Molin, 1860) (35561) & A & - & $30.0(1)$ \\
\hline \multicolumn{4}{|l|}{ Adenophorea } \\
\hline \multicolumn{4}{|l|}{ Enoplida } \\
\hline \multicolumn{4}{|l|}{ Trichuridae } \\
\hline \multicolumn{4}{|l|}{ Capillariinae } \\
\hline Capillaria bovis (Schneider, 1906) (35566) & SI & $02-28$ & $15.0(2)$ \\
\hline
\end{tabular}

A - Abomasum; SI - Small Intestine

to elucidate the pathogenical effects of Haemonchus spp in grey-brocket deer and other Neotropical species.

Hoberg et al. (2002), based on the diagnosis of Ashworthius patriciapillitae Hoberg, Abrams, Carreño and Lichtenfels, 2002 in O. virginianus from Costa Rica, suggest that this genus is more adapted to the Odocoileinae than Haemonchus, and that previous reports of the latter in Neotropical deer may be due to misdiagnosis. Data of this study and previous works by Travassos (1937), Nascimento et al. (2000), and Uhart et al. (2003) confirm the occurrence of Haemonchus in Neotropical Odocoileinae, discarding misdiagnosis hypothesis.

Low abundances observed are similar to those reported by Prestwood et al. (1975), Prestwood et al. (1976), Díaz et al. (1977), and could be due to host-parasite equilibrium. The parasitic diversity observed differ from that of Deem et al. (2004), who reports only Moniezia Blanchard, 1891, Trichuris Roederer, 1761 and Taenia hydatigena Pallas, 1766 cysticerci in M. gouazoubira from Bolivia. This difference may be due to the meth- odology employed in that work, based on coproparasitological methods.

The abomasal spirurid Pygarginema verrucosa (Molin, 1860) Kadenazii, 1948 is first described in this host species, although previous diagnosis in other Neotropical deer (Grisi, 1975). However, controversial data on some morphological aspects of Pygarginema species (Chabaud and Rousselot, 1956) may lead to misindentification, hindering future systematic studies of this group. Herein, a detailed morphological description of this parasite is given.

Spirocercidae Chabaud, 1975

Ascaropsinae Alicata and McIntosh, 1933

Pygarginema verrucosa (Molin, 1860) Kadenazii, 1948

General: Whitish nematodes in vivo, with well-developed trapezoidal lips and strong, striated protorhabdion (Figures 1 and 2), typical of the Ascaropsinae. Fine transversal cuticle striations may be observed all along the nematode body. Mouth opening surrounded by six lips, four medial-lateral and two lateral. A row of four papillae is observed surrounding the lips, with the pa- 

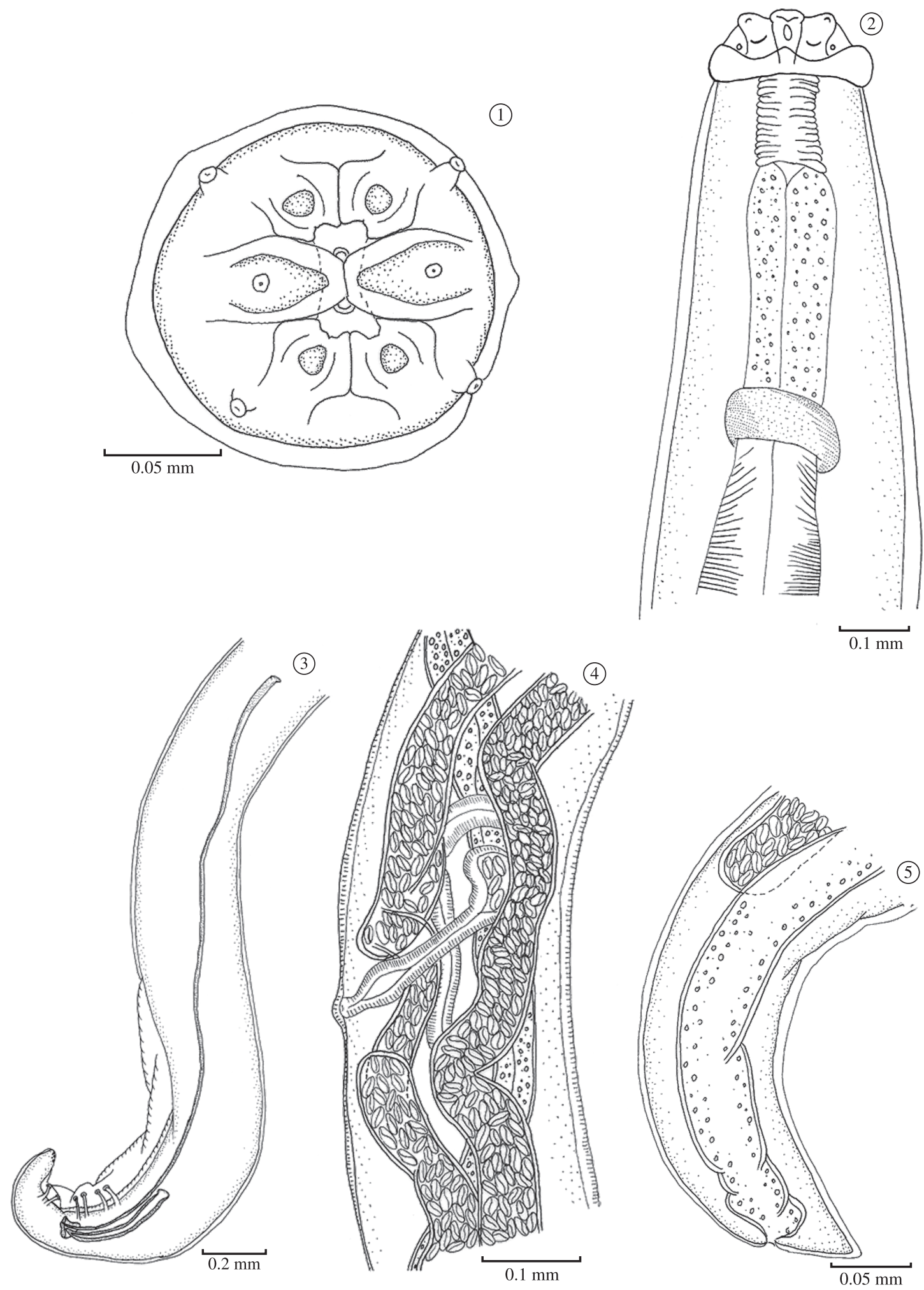

Figures 1-5. Pygarginema verrucosa. 1) Stoma, en face view; 2) Anterior ending, lateral view; 3) Male posterior portion, lateral view; 4) Vulvar region, lateral view; 5) Female posterior ending, lateral view. 
pillae originating close to the medial-lateral lips insertion. Amphids are observed next to the lateral lips origin, internally to the four papillae row. Each lip is endowed with a large, parenchimatous, refringent lobe (Figure 1). Deirids and lateral alae have not been observed on the studied specimens. The oesophagus is divided into two distinct portions: one glandular, and one pronouncedly muscular (Figure 2).

Male: Total body length $11.7529( \pm 0.2403)$, width $0.3666( \pm 0.0154)$ at oesophagean-intestinal junction. Protorhabdion length is $0.0552( \pm 0.0079)$. Oesophagus is $1.9328( \pm 0.0287)$ long, with glandular and muscular portions measuring $0.2476( \pm 0.0116)$ and $1.6851( \pm 0.0226)$, respectively. Nerve ring and excretory pore opening are situated $0.3885( \pm 0.0079)$ and $0.4285(n=1)$ from anterior ending. Spicules are unequal in shape and length. The right spicule is larger and sharp-tipped, 2.2444 $( \pm 0.0401)$ long. The left one is thicker than the right, with a slightly rounded tip, measuring $0.4037( \pm 0,0154)$. Gubernacule shape is kind of triangular, with maximum length of 0.0777 ( \pm 0.0082$)$. Strongly coiled tails, typical of the Spirurida, have been observed in all specimens. Consequently, only a lateral description of the caudal papillae could be accomplished. Four pairs of pre-anal and two pairs of post-anal pedunculated papillae, as well as five pairs of sessile papillae in the point of the tail have been observed. These sessile papillae are grouped in one cluster of four pairs of papillae slightly distant from the tail tip pair. The caudal alae are well-developed, with a fine striation on its surface (Figure 3 ).

Female: Total body length $16.6167( \pm 0.3288)$, width $0.3740( \pm 0.0274)$ at the esophageal-intestinal junction. Pharynx measures $0.0511( \pm 0.0032)$. Oesophagus total length is $2.5351( \pm 0.1012)$, and the glandular and muscular parts are $0.7666( \pm 0.0353)$ and $1.7685( \pm 0.0686)$ long. Nerve ring and excretory pore opening are 0.2925 $( \pm 0.0154)$ and $0.4074( \pm 0.0261$, only two specimens) distant from anterior ending. Didelphic females, with vulvar opening $8.5764( \pm 0.2012)$ from anterior ending. Thin-shelled, embryonated eggs in utero (Figure 4). Short and conical smooth tail, with sub-terminal anal opening, at $0.1740( \pm 0.0101)$ from tail tip (Figure 5).

\subsection{Taxonomic summary}

Hosts: M. nana (Hensel, 1872) (=Cervus nambi sensu Natterer, 1835), Blastocerus dichotomus (Illiger, 1815), O. bezoarticus (Linnaeus, 1758).

New host record: $M$. gouazoubira.

Habitat: Lumen of abomasum

New locality record: Pedro Gomes county, Mato Grosso do Sul state, Brazil (18 $08^{\circ}$ ' 25“ S and $54^{\circ} 32$ ' 15 "' W).
Deposited specimens: Voucher in CHIOC, under collection number 35561

Remarks: Species of Pygarginema Kadenatzii, 1948 have been described in Cervidae and Bovidae from Paleartical, Afrotropical (Chabaud and Rousselot, 1956) and Neotropical regions (Grisi, 1975). Smales (2004) considers this genus as part of the Cosmopolitan group of the Ascaropsinae Alicata and MacIntosch, 1933. The type species of the genus, P. skrjabini Kadenatzii, 1948, was described based only on female nematodes obtained from Capreolus pygargus (Pallas, 1771) (Artyodactyla: Bovidae) (Chabaud and Rousselot, 1956). Kadenatzii (after Chabaud and Rousselot, 1956) also considers Spiroptera verrucosa Molin, 1859 as a member of this newly erected genus, naming it $P$. verrucosa (Molin, 1859) Kadenatzii, 1948. Later, Lubimov (after Chabaud and Rousselot, 1956) describes another species of this genus based on male and female nematodes obtained from Cervus nippon Temminck, 1838, naming it $P$. cervi Lubimov, 1953. Chabaud and Rousselot (1956), studying nematode parasites of Cephalophus dorsalis Gray, 1846 from Congo, Africa, describe $P$. africana Chabaud and Rousselot, 1956, places $P$. cervi as junior synonym of $P$. skrjabini, and comment on the morphology of the three valid species of the genus, regarding that $P$. verrucosa male caudal morphology is slightly different of the other two species.

Grisi (1975) reports the presence of three pairs of post-cloacal papillae, with the first pair next to the cloacal opening. None of the analysed specimens showed these extra papillae. Therefore, the irregularities observed in the caudal alae internal face may have lead to this misinterpretation.

The labial morphology of $P$. verrucosa is very similar to $P$. africana and $P$. cervi, but with a lesser number of papillae.

\section{Conclusions}

Based on the obtained data, the authors suggest that the studied $M$. gouazoubira helminthfauna may be derived from that of domestic cattle. Still, $H$. contortus and $H$. similis Travassos, 1914 were the parasites with the most expressive descriptors of infection, suggesting a good adaptation on this host species. This deer is reported as a new host for P. verrucosa, whose morphology is described here.

Acknowledgements - The authors would like to thank FAPESP for financial support (proc. number 03/05748-1), and Dr. Elizabeth Moreira dos Santos Schmidt and the anonymous reviewer for valuable suggestions and their kind review of the manuscript. 


\section{References}

ALBON, SD., STIEN, A., IRVINE, RJ., LANGVATN, R., ROPSTAD, E. and HALVORSEN, O., 2002. The role of parasites in the dynamics of a reindeer population. Proceedings of the Royal Society B, vol. 269, p. 1625-1632.

BUSH, AO., LAFFERTY, KD., LOTZ, JM. and SHOSTAK, AW., 1997. Parasitology meets ecology on its own terms: Margolis et al. revisited. Journal of Parasitology, vol. 83, no. 4, p. $575-583$.

CATTO, JB. and FURLONG, J., 1983. Nematodioses gastrintestinais em bezerros zebus no pantanal matogrossense: III sub-região de Paiaguás. Pesquisa Agropecuária Brasileira, vol. 18 , no. 11 , p. $1265-1271$.

CATTO, JB., SERENO, JRB. and COMASTRI-FILHO, JA., 1997. Tecnologias e informações para a pecuária de corte no Pantanal. Corumbá: EMBRAPA. 182 p.

CHABAUD, AG. and ROUSSELOT, R., 1956. Pygarginema africana n. sp. (Nematoda: Ascaropsinae) parasite d'un céphalophe africain. Annales de Parasitologie Humaine et Comparee, vol. 31, no. 3, p. 248-254.

CLOUT, MN., 2002. Biodiversity loss caused by invasive alien vertebrates. European Journal of Wildlife Research, vol. 48, no. 1, p. $51-58$.

Convention on International Trade in Endangered Species of Wild Fauna and Flora-CITES, 2006. Canada. Available from: $<$ http://www.cites.ec.gc.ca/eng/sct0/index_e.cfm>. Access in: 28/10/2006.

DEEM, SL., NOSS, AJ., VILLARROEL, R., UHART, MM. and KARESH, WB., 2004. Disease survey of free-ranging grey brocket deer (Mazama gouazoubira) in the Gran Chaco, Bolivia. Journal of Wildlife Diseases, vol. 40, no. 1, p. 92-98.

DÍAZ, L., RÍOSECO, H. and CUBILLOS, V., 1977. Prospección y patología del parasitismo en cérvidos autóctonos y exóticos en el sur de Chile. Boletin Chileno Parasitologia, vol. 32, no. 3-4, p. $86-89$.

DURETTE-DESSET, MC., 1983. Keys to the genera of the Superfamily Trichostrongyloidea. In ANDERSON, RC., CHABAUD, AG. and WILMOTT, S. (Eds.). CIH keys to the nematode parasites of vertebrates. Farnham Royal: Commonwealth Agricultural Bureaux. 86 p. (no. 10).

FOREYT, W. and TRAINER, DC., 1970. Experimental haemonchosis in white-tailed deer. Journal of Wildlife Diseases, vol. 6 , no. 1, p. 36-42.

GIBBONS, LM. and KHALIL, LF., 1982. A key for identification of the genera of the nematode family Trichostrongylidae Leiper, 1912. Journal of Helminthology, vol. 56, p. 182-233.

GRISI, L., 1975. Sobre Pygarginema verrucosa (Molin, 1860) em Ozotocerus bezoarticus L., no estado de Mato Grosso (Nematoda, Spiruridae). Revista Brasileira de Biologia, vol. 35, no. 1 , p. 109-112

HOBERG, EP., ABRAMS, A., CARRENO, RA. and LICHTENFELS, JR., 2002. Ashworthius patriciapilittae n. sp. (Trichostrongyloidea: Haemonchinae), an abomasal nematode in Odocoileus virginianus from Costa Rica, and a new record for species of the genus in the Western hemisphere. Journal of Parasitology, vol. 88, no. 6, p. 1187-1199.

Instituto Brasileiro do Meio Ambiente e Recursos Naturais Renováveis - IBAMA, 2003. Lista das espécies da fauna brasileira ameaçadas de extinção. Brasília.

International Union for Conservation of Nature - IUCN, 2006. The 2006 IUCN Red List of Threatened Species. Cambridge: IUCN. Available from: <http://www.redlist.org >. Access in: 28/10/2006.

MCKENZIE, ME. and DAVIDSON, WR., 1989. Helminths parasites of intermingling axis deer, wild swine and domestic cattle from the island of Molokai, Hawaii. Journal of Wildlife Diseases, vol. 25, no. 2, p. 253-257.

NASCIMENTO, AA., BONUTI, MR., MAPELI, EB., TEBALDI, JH., ARANTES, IG. and ZETTERMANN, CD., 2000. Infecções naturais em cervídeos (Mammalia: Cervidae) procedentes dos Estados do Mato Grosso do Sul e São Paulo por nematódeos Trichostrongyloidea Cram, 1927. Brazilian Journal of Veterinary Research and Animal Science, vol. 37, no. 1, p. 153-158.

NOWAK, RM., 1999. Walker's mammals of the world. 6 ed. Baltimore: Johns Hopkins University Press. p. 1051-1238. (vol. 2).

PINDER, L. and LEEUENBERG, F., 1997. Veado-catingueiro (Mazama gouazoubira Fischer, 1814). In BARBANTI, JMB. (Ed.). Biologia e conservação de Cervídeos Sul-americanos: Blastocerus, Ozotocerus e Mazama. Jaboticabal: FUNEP. p. $60-67$.

PRESTWOOD, AK. and KELLOGG, FE., 1971. Naturally occurring haemonchosis in a white-tailed deer. Journal of Wildlife Diseases, vol. 7, no. 2, p. 133-134.

PRESTWOOD, AK., KELLOGG, FE., PURSGLOVE, SR. and HAYES, FA., 1975. Helminthic parasitism among intermingling insular populations of white-tailed deer, feral cattle and feral swine. Journal of the American Veterinary Medical Association, vol. 166, no. 1, p. 787-790.

PRESTWOOD, AK., PURSGLOVE, SR. and HAYES, FA., 1976. Parasitism among white-tailed deer and domestic sheep on common range. Journal of Wildlife Diseases, vol. 12, no. 3, p. 380-385.

RODRIGUES, FHG., MEDRI, IM., TOMAS, WM. and MOURÃO, GM., 2002. Revisão do conhecimento sobre ocorrência e distribuição de mamíferos do Pantanal. Corumbá: EMBRAPA. 196 p. (série documentos no. 38).

SILVA, JSV. and ABDON, MM., 1998. Delimitação do pantanal brasileiro e suas sub-regiões. Pesquisa Agropecuária Brasileira, vol. 33, p. 1703-1711.

SILVA, MIS., NASCIMENTO, AA., BONUTI, MR., MAPELI, EB. and ARANTES, IG., 1999. Ascaropsinae (Alicata and McIntosch, 1933) parasites of deer from the lowlands region of the State of Mato Grosso do Sul, Brazil. Brazilian Journal of Veterinary Parasitology, vol. 8, no. 2, p. 133-136.

SILVA, MP., MAURO, R., MOURÃO, GM. and COUTINHO, M., 2000. Distribuição e quantificação de classes de vegetação do Pantanal através de levantamento aéreo. Revista Brasileira de Botânica, vol. 23, no. 2, p. 143-152.

SMALES, LR., 2004. Spirosprattus scyphiformis n. g., n. sp. (Nematoda: Spirurida), from the Cape York Rat, Rattus leucopus 
(Gray, 1867) (Rodentia: Muridae), in Cape York, Australia. Comparative Parasitology, vol. 71, no. 2, p. 154-185.

TRAVASSOS, L., 1937. Revisão da família Trichostrongylidae Leiper, 1912. Monographias do Instituto Oswaldo Cruz, no. 1, p. 1-512.

UHART, MM., VILA, AR., BEADE, MS., BALCARCE, A. and KARESH, WB., 2003. Health evaluation of Pampas deer
(Ozotocerus bezoarticus celer) at campos Del Tuyú Wildlife Reserve, Argentina. Journal of Wildlife Diseases, vol. 39, no. 4, p. $887-893$.

VICENTE, JJ., RODRIGUES, HO., GOMES, DC. and PINTO, RM., 1997. Nematóides do Brasil. Revista Brasileira de Zoologia, vol. 14, no. 1, p. 1-194. (parte V, Nematódeos de mamíferos). 